\title{
Sensitivity of the North Atlantic climate to Greenland Ice Sheet melting during the Last Interglacial
}

\author{
P. Bakker ${ }^{1}$, C. J. Van Meerbeeck ${ }^{2}$, and H. Renssen ${ }^{1}$ \\ ${ }^{1}$ Earth \& Climate Cluster, Department of Earth Sciences, VU University Amsterdam, 1081HV Amsterdam, The Netherlands \\ ${ }^{2}$ The Caribbean Institute for Meteorology and Hydrology, Husbands, 23006 St. James, Barbados
}

Correspondence to: P. Bakker (p.bakker@vu.nl)

Received: 9 August 2011 - Published in Clim. Past Discuss.: 31 August 2011

Revised: 6 May 2012 - Accepted: 10 May 2012 - Published: 1 June 2012

\begin{abstract}
During the Last Interglacial (LIG; $\sim 130000 \mathrm{yr}$ BP), part of the Greenland Ice Sheet (GIS) melted due to a warmer than present-day climate. However, the impact of this melting on the LIG climate in the North Atlantic region is relatively unknown. Using the LOVECLIM Earth system model of intermediate complexity, we have systematically tested the sensitivity of the LIG climate to increased freshwater runoff from the GIS. In addition, experiments have been performed to investigate the impact of an idealized reduction of both surface elevation and extent of the GIS on the LIG climate. Based on changes in the maximum sea-ice cover and the strength of the overturning circulation, three regimes have been identified, which are characterized by a specific pattern of surface temperature change in the North Atlantic region. By comparing the simulated deep ocean circulation with proxy-based reconstructions, the most realistic simulated climate could be discerned. The resulting climate is characterized by a shutdown of deep convection and a subsequent $\sim 4{ }^{\circ} \mathrm{C}$ cooling in the Labrador Sea. Furthermore, a cooling of $\sim 1^{\circ} \mathrm{C}$ over the North Atlantic Ocean between $40^{\circ} \mathrm{N}$ and $70^{\circ} \mathrm{N}$ is seen. The prescribed reduction in surface elevation and extent of the GIS results in a local warming of up to $4{ }^{\circ} \mathrm{C}$ and amplifies the freshwater-forced reduction in deep convection and the resultant cooling in the Nordic Seas. A further comparison of simulated summer temperatures with both continental and oceanic proxy records reveals that the partial melting of the GIS during the LIG could have delayed maximum summer temperatures in the western part of the North Atlantic region relative to the insolation maximum.
\end{abstract}

\section{Introduction}

Measurements and modelling studies predict that the Greenland Ice Sheet (GIS) is likely to partially melt in the future (Driesschaert et al., 2007; Rignot et al., 2011) under the influence of a warmer climate (Solomon et al., 2007). The implications of enhanced GIS melting are a central theme in the current climate change debate, not only because of the potential impact on eustatic sea-level rise, but also because of the possible impact on the overturning circulation. However, the relationship between enhanced GIS melting and the ocean circulation is poorly understood (Swingedouw and Braconnot, 2007). It is therefore crucial to study the impact of GIS melting on the Last Interglacial climate (LIG, 130000 to $116000 \mathrm{yr} \mathrm{BP}$ ), which was warmer than present-day (CAPEmembers, 2006), and during which the GIS was also significantly reduced in size (Alley et al., 2010).

GIS melting is accompanied by an increased flow of freshwater into the surrounding oceans. This would lower the density of the surface ocean waters and potentially alter the strength of the Atlantic Meridional Overturning Circulation (AMOC). Since the AMOC transports warm, saline waters northwards from the equator along its wind- and densitydriven upper limb (Broecker et al., 1990; Schmitz, 1995), changes in its heat transport may greatly impact temperatures in regions such as northwestern Europe (Kuhlbrodt et al., 2007). In the subpolar North Atlantic Ocean these surface waters are sufficiently cooled until they overcome the vertical density gradient in the water column. At that point deep convection occurs forming North Atlantic Deep Water (NADW), a high density water mass flowing southward at depth (Schmitz, 1995; Weaver et al., 1999). Nowadays, deep 
convection in the North Atlantic mainly occurs in two regions, the Labrador Sea and the Nordic Seas, where Labrador Sea Water (LSW) and Nordic Seas Deep Water (NSDW) are formed. Deep convection leading to NADW production further occurs in the Irminger Sea, but its importance for the AMOC is not yet fully established (Bacon et al., 2003).

Experiments with different climate models of low to intermediate complexity indicate that the AMOC is a highly non-linear system with multiple equilibrium states, including hysteresis behaviour in response to changes in the freshwater budget of the Atlantic region (Rahmstorf, 1995; Rahmstorf et al., 2005). Although hysteresis is a common feature in these types of models, their sensitivity to a change in the freshwater budget differs greatly, as does the proximity of the present-day climate to the bifurcation point (Stommel, 1961; Rahmstorf et al., 2005). In some models it takes a freshwater flux of less than $0.1 \mathrm{~Sv}$ to substantially weaken the AMOC, while in others more than $0.5 \mathrm{~Sv}$ is needed (Rahmstorf et al., 2005). A close relationship between changes in the freshwater budget of the North Atlantic and the overturning circulation has also been suggested by geological data. An example is the Holocene $8.2 \mathrm{ka} \mathrm{BP}$ cooling event during which the AMOC was weakened by a catastrophic release of meltwater from glacial lakes Agassiz and Ojibway (Barber et al., 1999; Renssen et al., 2001). However, while modelling studies have shown that the relationship between changes in the freshwater budget and the AMOC strongly depends on which region is perturbed (Smith and Gregory, 2009; Roche et al., 2010), the impact of increased runoff from the GIS, possibly a critical region in the near future, is still relatively unknown.

The future evolution of the GIS under the influence of different greenhouse gas scenarios and the resulting impact on the freshwater runoff and ocean circulation have been simulated by Ridley et al. (2005) and Driesschaert et al. (2007) using coupled climate-ice-sheet models. Both show that the GIS is likely to lose mass, but a noticeable weakening of the AMOC is only found for a very strong increase of greenhouse gas concentrations (i.e. the upper range of IPCC climate change scenarios; Nakicenovic et al., 2000). Using a similar approach, Otto-Bliesner et al. (2006), modelling the evolution of the GIS during the LIG, found a slightly reduced AMOC due to enhanced melting of the GIS. A shutdown of the overturning circulation under the influence of GIS melting has thus far not been found in modelling studies, indicating that this is not a likely scenario, neither for the near future nor the LIG. However, it has been suggested that in climate models the sensitivity of the AMOC to changes in the freshwater budget in the North Atlantic is systematically too low (Hofmann and Rahmstorf, 2009).

Because the relationship between GIS melting and the AMOC is highly model-dependent, it is important to constrain models with proxy-based reconstructions. For example, reconstructions of both deep ocean circulation and the magnitude and duration of enhanced GIS melting can be used to constrain models for the LIG period. Reconstructions of ocean circulation show that deep convection in the Nordic Seas was probably comparable to present-day, but the timing of maximum strength is still open to debate (Cortijo et al., 1994, 1999; Rasmussen et al., 2003; Bauch and Erlenkeuser, 2008; Van Nieuwenhove et al., 2008, 2011; Govin et al., 2012). Nevertheless, reconstructions of LSW formation for the LIG show that it was either present (Rasmussen et al., 2003), weakened and/or shoaled (Hodell et al., 2009; Evans et al., 2007), or that it was absent altogether (Hillaire-Marcel et al., 2001). Most of what we know with respect to the magnitude and duration of enhanced GIS melting during the LIG is inferred from sea-level curves, which were reconstructed from coral reefs in Australia, Bermuda, the Bahamas and the Florida Keys. These suggest a LIG sea-level high stand at least $6 \mathrm{~m}$ above the present-day level (Alley et al., 2010, and references therein). However, there is no direct way to infer the specific contribution of the GIS to the total sea-level rise from these reconstructions. Therefore, a wide range of estimates for the GIS contribution exists, ranging from as little as $1-2 \mathrm{~m}$ to up to 5-6m (Table 1; Cuffey and Marshall, 2000; Tarasov and Peltier, 2003; Lhomme et al., 2005; OttoBliesner et al., 2006; Carlson et al., 2008; Colville et al., 2011).

The impact of GIS melting on the climate not only depends on the volume of ice lost, but also on the temporal scale over which this occurred. However, the dating of coral reef samples is still problematic for the LIG period (Rohling et al., 2008), with the period of sea-level high stand estimated to have started between 136 and $127 \mathrm{ka} \mathrm{BP}$ and ended between 122 and $115 \mathrm{ka} \mathrm{BP}$ (Chen et al., 1991; Stirling et al., 1995, 1998; Vezina et al., 1999; Israelson and Wohlfarth, 1999; McCulloch and Esat, 2000; Muhs et al., 2002; Rohling et al., 2008). Therefore, constraining the possible melt rate of the GIS during the LIG results in a wide range of values, with a maximum flux of $0.013 \mathrm{~Sv}$ for an ice-volume equivalent to $5.5 \mathrm{~m}$ of sea-level change occurring in $5 \mathrm{kyr}$.

The rate of LIG global sea-level change is better constrained but includes an important - yet unknown - contribution from the GIS (Rohling et al., 2008). In a probabilistic assessment of sea-level change by Kopp et al. (2009), they found that fluxes probably exceeded $0.064 \mathrm{~Sv}$ for a period of around $1000 \mathrm{yr}$, but it is unlikely that they exceeded 0.11 Sv. However, Rohling et al. (2008) have reconstructed a maximum rate of LIG sea-level change of $\sim 0.29 \mathrm{~Sv}\left(2.5 \mathrm{~m} \mathrm{century}^{-1}\right)$ for a period of at least $\sim 400 \mathrm{yr}$. This suggests that for several centuries the flux of freshwater into the surface ocean waters around Greenland may have been much larger than $0.013 \mathrm{~Sv}$. The resulting range of possible melt rates, coupled with the fact that modelling experiments have shown a strong non-linear relationship between the magnitude and impact of freshwater perturbations (Renssen et al., 2002; Rahmstorf et al., 2005; Wiersma and Renssen, 2006), highlights the necessity to cover a large range of scenarios. 
Table 1. Overview of estimated GIS contribution (m) to LIG sealevel high stand. Both data and combined model-data studies are listed.

\begin{tabular}{ll}
\hline Author & Range \\
\hline Cuffey and Marshall (2000) & $4-5.5$ \\
Tarasov and Peltier (2003) & $2.7-4.5$ \\
Lhomme et al. (2005) & $3.5-4.5$ \\
Otto-Bliesner et al. (2006) & $1.9-3$ \\
Carlson et al. (2008) & $2-5.5$ \\
Colville et al. (2011) & $1.6-2.2$ \\
\hline
\end{tabular}

Because of the aforementioned difficulties - modeldependent climate sensitivity, uncertainty in reconstructions of both past ocean circulation and the evolution of the GIS meltwater flux - the impact of GIS melting on the AMOC and the climate must be assessed systematically. Therefore, we performed a suite of 24 climate simulations with the LOVECLIM three-dimensional Earth system model, in which an early LIG climate state is perturbed by systematically increasing GIS melting rates - ranging from $0.0065 \mathrm{~Sv}$ to up to $0.299 \mathrm{~Sv}\left(1 \mathrm{~Sv}=10^{6} \mathrm{~m}^{3} \mathrm{~s}^{-1}\right)$. The selected upper range of GIS melt rates is unlikely to have occurred for more than several centuries during the LIG. Nevertheless, to fully describe the possible impact of GIS melt on the LIG climate, we investigated the entire range of fluxes.

To further investigate the climatic impact of a lower elevation and decreased extent of the GIS as a consequence of its partial melting, we carried out additional sensitivity experiments. Our focus in the latter experiments is on the impact of GIS melting on both deep ocean circulation and surface climate in the North Atlantic region. Model results are summarized by defining key regions that exhibited significant changes in surface climate. In a second step, the most plausible GIS melt scenario is selected by comparing the simulated deep ocean circulation with proxy-based reconstructions. Finally, we make a first attempt at assessing the impact of GIS decay on the early LIG climate by comparing reconstructed surface temperatures with those simulated in the most probable GIS melt scenario.

\section{Model and experimental setup}

We have used the Earth system model of intermediate complexity (EMIC) LOVECLIM (version 1.2; Goosse et al., 2010), which includes a representation of the atmosphere, ocean, sea-ice, and the land-surface and its vegetation. The atmospheric component is ECBilt (Opsteegh et al., 1998), a spectral T21, three-level quasi-geostrophic model. The seaice-ocean component is CLIO3 (Goosse and Fichefet, 1999), a free-surface primitive equation model with a horizontal resolution of $3^{\circ}$ longitude by $3^{\circ}$ latitude and 20 vertical levels. The vegetation component is VECODE (Brovkin et al.,
2002), in which dynamical vegetation changes are simulated as a function of the climatic conditions. In this study no interactive ice-sheet model was used. Therefore we could fully control the elevation, extent and runoff of the GIS and, thus, separately study the climatic impact of the different processes accompanying a melting GIS.

The climate sensitivity of LOVECLIM1.2 to a doubling of the atmospheric $\mathrm{CO} 2$ concentration is at the lower end of the range found in global climate models $\left(1.9^{\circ} \mathrm{C}\right.$ after $1000 \mathrm{yr}$; Goosse et al., 2010). The simulated present-day deep ocean circulation in LOVECLIM1.2 compares reasonably well with other model results, with a maximum overturning streamfunction in the North Atlantic of $23 \mathrm{~Sv}$ and an export towards the Southern Ocean of $13 \mathrm{~Sv}$. In correspondence with observations over recent decades, deep convection in LOVECLIM1.2 takes place in both the Labrador and Nordic Seas (Goosse et al., 2010). The present-day deep ocean circulation in LOVECLIM1.2 is somewhat more sensitive to perturbations of the freshwater budget (Goosse et al., 2010) than in an earlier version of the model (namely ECBiltCLIO), a version for which the sensitivity was found to be very similar to atmosphere-ocean general circulation models (AOGCMs; Rahmstorf et al., 2005). Model-data comparisons for different climatic settings like the $8.2 \mathrm{kaBP}$ event (Wiersma and Renssen, 2006) and the last deglaciation (Renssen et al., 2009) showed that the sensitivity of the AMOC to a perturbation of the freshwater budget is reasonable in our model.

Between 130 and $127 \mathrm{ka} \mathrm{BP}$, a different orbital configuration caused a large positive Northern Hemisphere insolation anomaly compared to present-day, particularly in late spring and early summer. The maximum insolation anomaly at the top of the atmosphere during the LIG exceeded $60 \mathrm{~W} \mathrm{~m}^{-2}$ at high northern latitudes in the months May to June, while the global annual mean anomaly was as little as $2 \mathrm{~W} \mathrm{~m}^{-2}$ (Berger, 1978). As the GIS has shown to be particularly sensitive to insolation changes in late spring and early summer (Krabill et al., 2004; Otto-Bliesner et al., 2006), it is likely that the early LIG insolation maximum resulted in maximum ablation of the GIS (Otto-Bliesner et al., 2006). This has also been found in deep sea geochemical proxies, which indicate a large and steady runoff between 132 and $120 \mathrm{kaBP}$ (Carlson et al., 2008) and a minimum GIS size as early as $127 \mathrm{ka} \mathrm{BP}$ (Lhomme et al., 2005). We therefore force the LIG climate simulations with orbital and greenhouse gas concentrations as reconstructed for $130 \mathrm{ka} \mathrm{BP}$ (Table 2); $130 \mathrm{kaBP}$ forcing values are in line with the PMIP3 protocol (http://pmip3.lsce.ipsl.fr/). Note that in the model and also in Fig. 4 we make use of a calendar in which the vernal equinox is fixed at 21 March at noon and the months or seasons are defined based on the present-day calendar (cf. Joussaume and Braconnot, 1997).

Both the control simulation for the LIG (LIG-ctrl) and the pre-industrial (PI; orbital and greenhouse gas forcing for $1750 \mathrm{AD}$ ) were spun up for $3000 \mathrm{yr}$ to ensure 
Table 2. Forcing applied to LIG climate simulations. Values are for $130 \mathrm{ka} \mathrm{BP}$ and in line with PMIP3 agreements.

\begin{tabular}{lll}
\hline Orbital parameters & Eccentricity & 0.038209 \\
& Obliquity & $24.242^{\circ}$ \\
& Perihelion- $180^{\circ}$ & $228.32^{\circ}$ \\
Greenhouse gas & $\mathrm{CO}_{2}$ & $257 \mathrm{ppm}$ \\
concentrations & $\mathrm{CH}_{4}$ & $512 \mathrm{ppb}$ \\
& $\mathrm{N}_{2} \mathrm{O}$ & $239 \mathrm{ppb}$ \\
FWF sensitivity & & $0.0065 \mathrm{~Sv}$ to \\
experiments & & $0.299 \mathrm{~Sv}$ \\
\hline
\end{tabular}

quasi-equilibrium conditions in all components of the model, in particular the deep ocean. The land-sea mask, the GIS surface elevation and extent were fixed at PI configuration. As the difference in sea level between the two periods is only a couple of metres, the effects on the results of having a fixed land-sea mask are expected to be negligible. From the quasi-equilibrium LIG-ctrl simulation, two sets of experiments were performed to investigate the different effects of the partial melting of the GIS: increased runoff, and reduced elevation and extent of the ice sheet. All simulations have a duration of $500 \mathrm{yr}$, during which the forcings were kept constant. Results presented are averages calculated over the last $150 \mathrm{yr}$ of the simulations.

In the first series of experiments, referred to as freshwater forcing (FWF), the $130 \mathrm{ka}$ BP climate was perturbed with a constant runoff flux from the GIS in addition to the runoff already calculated by the model (i.e. the sum of all excess precipitation and snow melt; Opsteegh et al., 1998). The total runoff was then evenly distributed over 10 adjacent oceanic grid-cells corresponding to the river outlets of the Greenland landmass (Fig. 1). The FWF-scenarios are multiples of the best estimate $(0.013 \mathrm{~Sv})$ of Otto-Bliesner et al. (2006) and cover the full range of possible fluxes, from 0.5 times up to 23 times $0.013 \mathrm{~Sv}(0.0065-0.299 \mathrm{~Sv})$. As all FWF experiments have a duration of $500 \mathrm{yr}$, the total volume of additional meltwater input to the ocean differs between the simulations, from $\sim 2 \%$ to up to $\sim 115 \%$ of the total PI volume of the GIS. Running experiments with constant forcings and of limited duration (i.e. $500 \mathrm{yr}$ ) implies a number of limitations. Most importantly, it cannot be inferred whether or not the simulated climatic conditions would be transient or stable over a prolonged period of time.

To investigate the influence of a reduced GIS surface elevation and changes in the extent of the ice sheet, a second set of sensitivity experiments was performed. In these experiments, the GIS surface elevation was lowered in a rudimentary way, corresponding to a $30 \%$ decrease of the ice volume. All grid cells of the PI ice sheet were equally lowered until either bedrock was reached for a particular grid cell or the total volume reduction of $30 \%$ was obtained. The altitude of the bedrock underneath the present-day GIS is deduced from topographic maps provided by the NOAA-database
(Hastings et al., 1999), and for simplicity we did not take isostatic rebound into account. This approach resulted in a configuration of the LIG GIS consisting of a single ice dome over central and northern Greenland and ice-free conditions over the southern, northwestern and northeastern parts of Greenland (Fig. 1). At these ice-free locales vegetation was allowed to develop, which results in a strong decrease of the surface albedo. This configuration is in broad agreement with reconstructions, although there are some differences. Most notably, reconstructions show a reduced elevation of the top of the ice sheet by $300-500 \mathrm{~m}$ in relation to modern-day (OttoBliesner et al., 2006; Masson-Delmotte et al., 2011), whereas our configuration shows a reduced elevation of $700 \mathrm{~m}$. Also, there is an on-going debate whether or not the southern dome of the GIS remained, and it has also been suggested that the ice sheet was probably steeper, as melting concentrated on the fringes (Koerner, 1989; Letréguilly et al., 1991; Cuffey and Marshall, 2000; Lhomme et al., 2005; Otto-Bliesner et al., 2006; Colville et al., 2011). However, we deem the strong simplification of the LIG GIS history, as implemented in our experiments, adequate, as the model's low resolution prevents applying further details. Nonetheless, the simplicity of this approach limits the evaluation of the atmospheric response to changes in elevation of the GIS. Finally, this highly simplified LIG configuration of the GIS has been applied to three of the FWF experiments, notably $0.013,0.052$ and $0.143 \mathrm{~Sv}$.

\section{Results and implications}

The ensemble of simulations forced with systematically increasing GIS melt rates provides us with an extensive range of climate states: from the warmer than present-day unperturbed $130 \mathrm{ka}$ BP climate state with a strong overturning circulation to a situation in which large scale overturning in the North Atlantic is shut down, leading to a strong surface cooling.

\subsection{Overturning circulation}

The simulations with increased runoff from the GIS show a clear impact on both the surface climate and the deep ocean circulation in the North Atlantic region. The changes in the strength of the AMOC, here taken as the maximum strength of the overturning streamfunction in the North Atlantic, are strongly related to the combined evolution of the sea-ice cover and deep convection in the two major regions of deep convection in the North Atlantic: the Labrador Sea and the Nordic Seas (Figs. 2 and 3). Furthermore, the simulated relationship between the FWF on the one hand and the sea-ice cover and the strength of the AMOC on the other hand changes with the magnitude of the FWF (Figs. 2 and 3 ). The relationship is characterized by two shifts, the first between a FWF of $0.039 \mathrm{~Sv}$ and $0.052 \mathrm{~Sv}$, and a second shift 


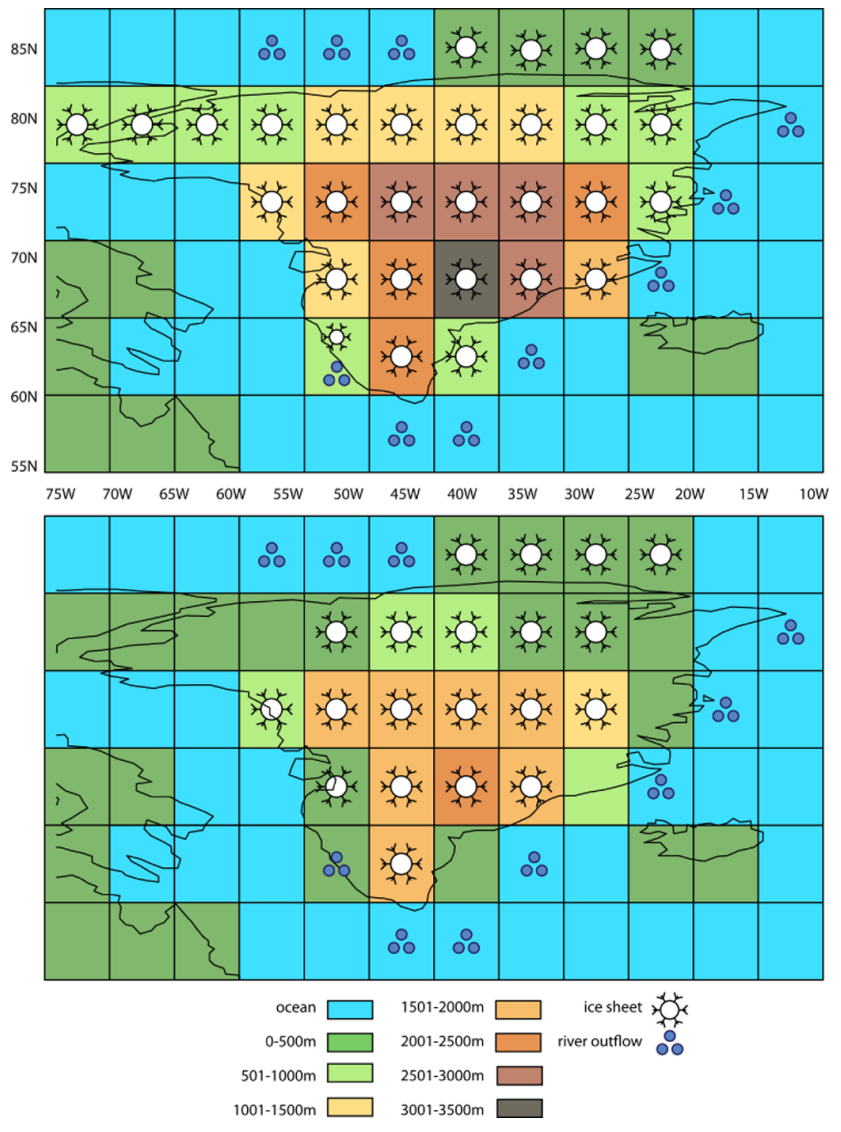

Fig. 1. Configuration of the GIS as used in the simulations. Depicted are the reference PI state (top panel) and the state with decreased elevation and extent of the GIS (lower panel). The latter state is obtained by decreasing the total ice volume of the GIS by $30 \%$. The elevation of the different grid cells is given in green and brownish colours, the ocean grid cells are blue, and different symbols indicate the river outflow points and the grid cells covered by ice. Many grid cells partially represent ocean and partially land. For this figure, a cell is depicted as ocean if at least $90 \%$ of the cell consists of ocean. As a result, the most easterly outflow point appears to be detached from the mainland; there is however both land and ocean in the adjacent grid cell. The outlines of the continents are for reference only.

between $0.130 \mathrm{~Sv}$ and $0.143 \mathrm{~Sv}$. These shifts are most apparent in the sea-ice cover changes in the Labrador Sea and the Nordic Seas (Fig. 2). Between a FWF of $0.039 \mathrm{~Sv}$ and $0.052 \mathrm{~Sv}$, the maximum sea-ice cover in the Labrador Sea jumps from a cover of around $28 \%$ up to a cover just under $60 \%$ (note that the absolute value of the sea-ice cover strongly depends on the exact definition of the region under consideration). For a larger FWF, the maximum sea-ice cover in the Labrador Sea remains relatively constant, between $60 \%$ and $70 \%$, but in the Nordic Seas a second shift is visible. For a FWF larger than $0.13 \mathrm{~Sv}$, the maximum seaice cover in the Nordic Seas shows a clear negative trend towards a maximum sea-ice cover close to $100 \%$. The two shifts are also visible in the evolution of the strength of the AMOC (Fig. 3). Concurrent with these changes in the maximum sea-ice cover, there are changes in the strength of deep convection in both the Labrador and the Nordic Seas. In our LIG-ctrl simulation, deep convection takes place in both the Labrador and the Nordic Seas, and the simulated strength of the AMOC of $\sim 22 \mathrm{~Sv}$ is very similar to the PI strength of $\sim 23 \mathrm{~Sv}$. For FWFs between $0.0065 \mathrm{~Sv}$ and $0.039 \mathrm{~Sv}$, the strength of the AMOC is reduced by up to $24 \%$ compared to the LIG-ctrl value. For a FWF of $0.052 \mathrm{~Sv}$, the strength of the AMOC is abruptly reduced to a value of $\sim 14 \mathrm{~Sv}, 39 \%$ weaker than in the LIG-ctrl simulation. In the same range of FWF values, the overturning strength in the Nordic Seas does not significantly decrease. However, when the FWF is greater than $0.130 \mathrm{~Sv}$, overturning in the Nordic Seas significantly weakens, and increasingly so for larger FWFs.

Because of non-linear processes and feedbacks between the ocean circulation and the sea-ice cover, our simulations result in 3 different climate regimes (Fig. 2), the main difference being the location of the principle site(s) of deep convection. For FWFs in the range $0-0.039 \mathrm{~Sv}$, the reduction in the strength of the AMOC is mainly due to a decrease in small-scale deep convection in the Irminger Sea (not shown). In addition, for FWFs at the upper end of this range, this is in conjunction with an initial decrease of deep convection in the Labrador Sea. Overall, it can be said that deep convection in this regime, which we refer to as regime 1, mainly takes place in both the Labrador and Nordic Seas. The maximum sea-ice cover is still limited in both regions. In regime 1, the evolution of deep convection in the Irminger and Labrador Seas is decoupled from the evolution of deep convection in the Nordic Seas with a small, albeit insignificant, increase occurring in the latter. Such an anticorrelated change between the major convection sites for moderate freshwater addition was also found by Stouffer et al. (2006). In regime 2 - i.e. the experiments with $0.052 \mathrm{~Sv}$ and $0.130 \mathrm{~Sv}$ FWF - the additional runoff from the GIS has sufficiently decreased the density of the surface waters in the Labrador Sea which, in combination with enhanced sea-ice formation, shuts down deep convection there. In this regime, large-scale deep convection only takes place in the Nordic Seas. The changes from regime 2 to regime 3 are more gradual. For a FWF larger than $0.130 \mathrm{~Sv}$, we defined a third regime, in which the overturning strength in the Nordic Seas is significantly weakened and the maximum sea-ice cover in the region increases more rapidly. A shutdown of deep convection and a full sea-ice cover in the Nordic Seas is reached for FWFs over $\sim 0.2 \mathrm{~Sv}$. In both regime 2 and regime 3 , the evolution of the overturning strength in the Nordic Seas is again coupled to the evolution of the strength of the AMOC. These three regimes or AMOC states have also been found in earlier model studies (Wood et al., 1999; Schulz et al., 2007).

In the remainder of this manuscript, the three regimes will be represented by the experiments with FWF-scenarios $0.013 \mathrm{~Sv}, \quad 0.052 \mathrm{~Sv}$ and $0.143 \mathrm{~Sv}$. Despite differences 


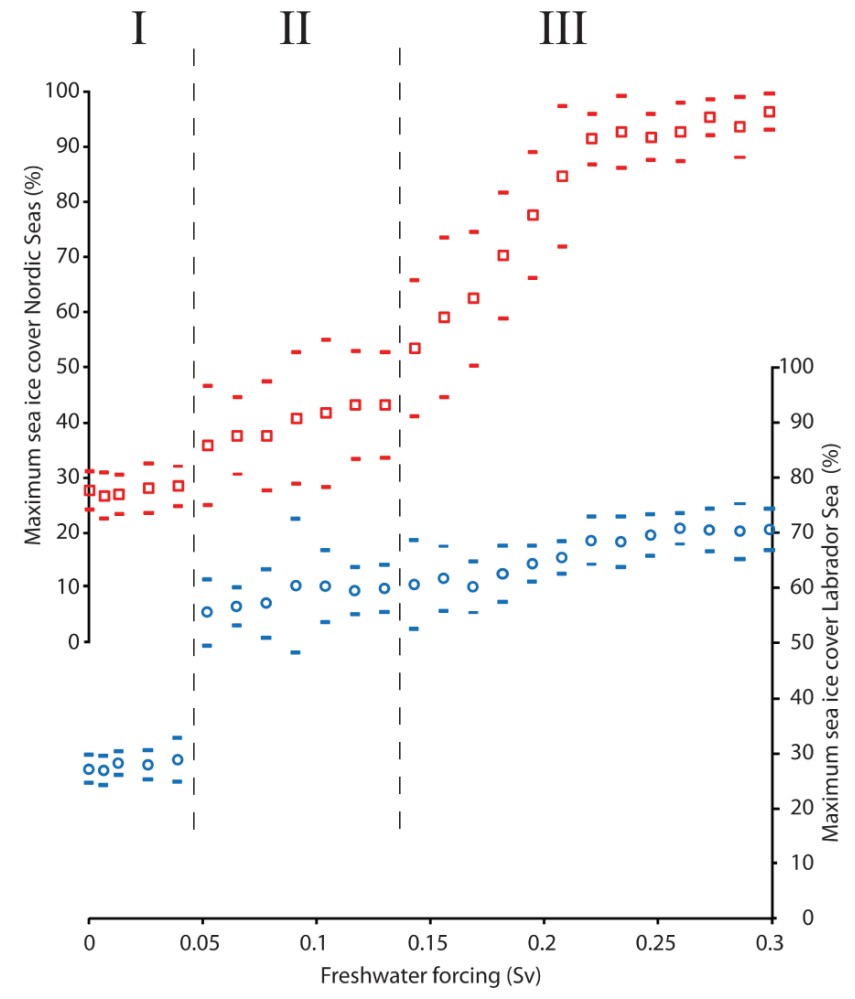

Fig. 2. Maximum (April) sea-ice cover (\%) in the Labrador Sea (blue circles) and in the Nordic Seas (red squares) as a function of the melt rate of the GIS (Sv). Horizontal bars indicate the $95 \%$ confidence interval $(2 \sigma)$. Values are averages over the last $150 \mathrm{yr}$ of the simulations. The vertical dashed lines distinguish the three different climate regimes.

between the simulated climates within one regime, this approach draws a clear picture of the large-scale climatic changes in the North Atlantic region as simulated for increasingly large GIS melt rates.

\subsection{Characteristics of the surface climate in the three different regimes}

In the different LIG climate simulations presented here, the surface climate in the North Atlantic region differs from the PI as a result of changes in both the orbital and greenhouse gas forcings as well as changes in the melt rate of the GIS. The characteristics of the surface climate are presented by describing significant changes in both July and January atmospheric surface temperatures and changes in sea surface salinity. By performing a t-test, we show where simulated anomalies are significantly larger than (simulated) internal LIG climate variability.

In the LIG-ctrl simulation, the impact of changes in the orbital and greenhouse gas forcings are visible (Fig. 5). The early LIG was characterized by a positive Northern Hemisphere July insolation anomaly of up to $40 \mathrm{~W} \mathrm{~m}^{-2}$ compared to present-day (Fig. 4). As a result, the LIG-ctrl simulation,

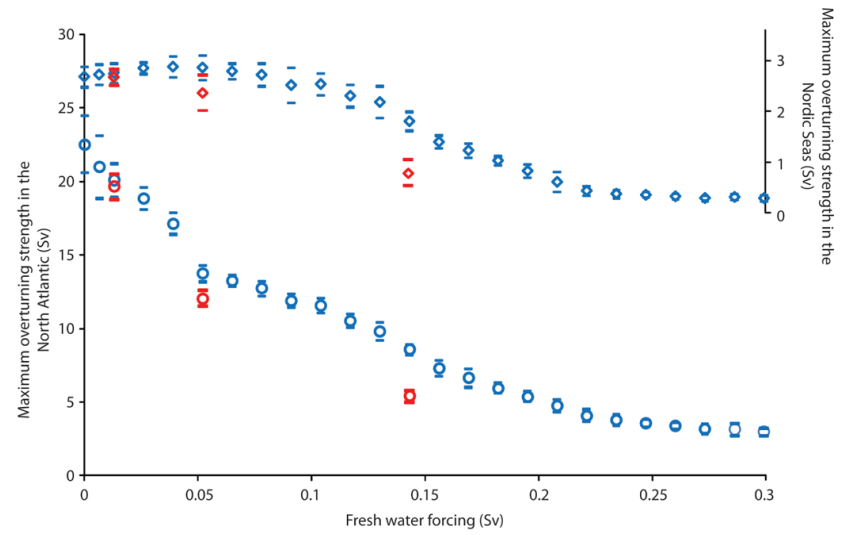

Fig. 3. The maximum strength of the overturning streamfunction (Sv) in the North Atlantic (circles) and Nordic Seas (diamonds) as a function of the freshwater forcing (Sv) from the GIS. The blue (red) symbols indicate simulations without (with) including changes in the elevation and extent of the GIS. Horizontal bars indicate the $95 \%$ confidence interval $(2 \sigma)$. All values are calculated over the last $150 \mathrm{yr}$ of the simulations. Simulated pre-industrial values are $23.65 \pm 0.97 \mathrm{~Sv}$ and $2.76 \pm 0.17 \mathrm{~Sv}$ for the maximum overturning strength in the North Atlantic and Nordic Seas respectively.

when compared to PI, shows a $+1-3{ }^{\circ} \mathrm{C}$ anomaly in July surface temperatures over most of the North Atlantic region and a $+5{ }^{\circ} \mathrm{C}$ anomaly over northwestern Europe and the Arctic region (Fig. 5). In contrast, mid to high latitude January insolation anomalies are only small (Fig. 4), resulting in LIG January surface temperatures similar to the PI for most of the North Atlantic region. There are however some exceptions, as over the far east of the European continent we simulate a more continental climate, which results in a $1-5^{\circ} \mathrm{C}$ lowering of LIG January surface temperatures when compared to PI (Fig. 5). The other exceptions are the high latitude areas, especially the far north of the Labrador Sea and around Svalbard, where a reduction in summer sea-ice extent (not shown) strongly affects January surface temperatures, resulting in a warming of $1-5^{\circ} \mathrm{C}$ compared to the PI. Otto-Bliesner et al. (2006) simulated similar $130 \mathrm{ka}$ BP surface temperatures using a full general circulation model, which corroborate our findings from the LIG-ctrl simulation. The surface salinity in our LIG-ctrl simulation (Fig. 5) differs from the PI only over the Arctic Ocean and along the southern shores of Greenland, where a decrease of up to $1 \mathrm{psu}$ (practical salinity units) results from small changes in the sea-ice cover and the hydrological cycle (not shown).

Forcing the model with an increased GIS melt rate, on top of LIG orbital and greenhouse gas forcings, results in very different patterns of surface temperature and sea surface salinity anomalies within the North Atlantic region. Note that, since our aim is to describe the impact of the melting GIS on the LIG climate, all following anomalies are calculated in relation to the LIG-ctrl simulation. Between the three different climate regimes, the region of largest significant 


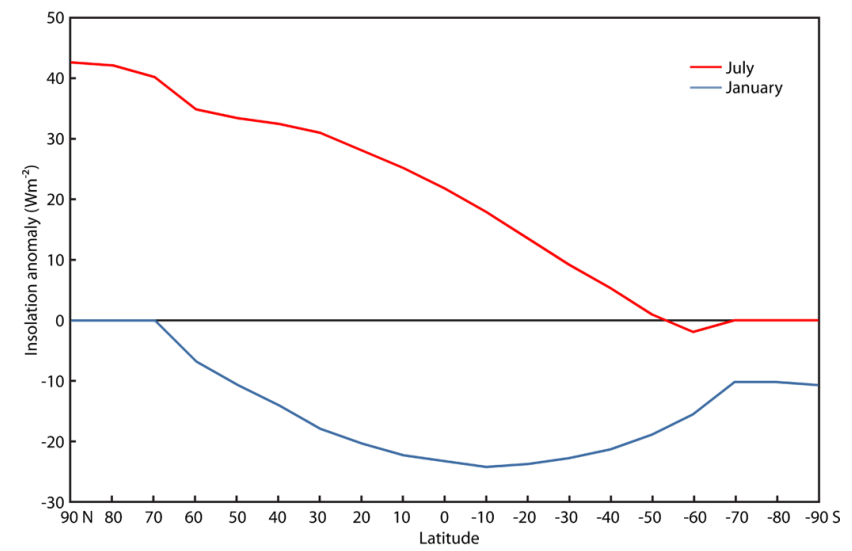

Fig. 4. Insolation anomalies $\left(\mathrm{W} \mathrm{m}^{-2}\right)$ for $130 \mathrm{ka} \mathrm{BP}$ as a function of latitude compared to pre-industrial values (Berger, 1978). The Northern Hemisphere winter (January) period is given in blue and the summer (July) period in red. The insolation is calculated using a calendar in which the vernal equinox is fixed at 21 March at noon and the months or seasons are defined based on the present-day calendar.

climate change, forced by GIS melt, shifts from the Irminger Sea to the Labrador Sea and finally to the Nordic Seas. In regime $1, \mathrm{a} \sim 1{ }^{\circ} \mathrm{C}$ decrease in July temperature is simulated over the Irminger Sea. In regime 2, we find July surface temperature anomalies of more than $-4{ }^{\circ} \mathrm{C}$ in the Labrador Sea and a $1^{\circ} \mathrm{C}$ cooling over most of the North Atlantic surface waters between $40^{\circ} \mathrm{N}$ and $70^{\circ} \mathrm{N}$. It is only in regime 3 that a clear $\sim 4^{\circ} \mathrm{C}$ cooling is seen in the Nordic Seas and over Scandinavia. However, even with such a large FWF only minor $\left(1^{\circ} \mathrm{C}\right)$ decreases in July surface temperatures are simulated over large parts of Greenland and Europe.

In the North Atlantic region, January and July surface temperature anomalies show a similar pattern. However, there are some notable exceptions. In regime 2 , we simulate a negative January surface temperature anomaly over central Greenland. Furthermore, the temperature decrease over the Barents Sea and Svalbard region found in regime 2 is stronger in January than it is in July.

The applied FWFs result in distinctive negative sea surface salinity anomalies. These anomalies again illustrate that the region of largest FWF impact shifts between the three regimes: from the Irminger Sea in regime 1 (up to $-0.5 \mathrm{psu}$ ) to the Labrador Sea in regime $2(-4 \mathrm{psu})$ and, finally, to the eastern side of the North Atlantic Ocean including the Nordic Seas (up to -2 psu) in regime 3 . The slowdown of the AMOC results in a clear positive salinity anomaly in the southwestern part of the North Atlantic Ocean (Fig. 5). Overall, the patterns of sea surface salinity anomalies show the route by which GIS meltwater is transported by the ocean currents. Freshwater, added to the surface ocean water around Greenland, is first advected by the surface currents into the Labrador Sea, after which it is carried to the eastern side of the basin via the southern part of the subpolar gyre.

\subsection{Influence of changes in topography and albedo}

We have incorporated changes in the surface elevation and extent of the GIS in order to study both their direct effect on the LIG climate of the North Atlantic region as well as the impact on the FWF-induced changes. In this section, we only concentrate on the changes in July surface temperatures because, for each regime, patterns of surface temperature and sea surface salinity anomalies within the North Atlantic region are generally consistent. Over the ice sheet, the lower elevation and the decrease in albedo result in a rise of July surface temperatures of up to $4^{\circ} \mathrm{C}$ (Fig. 6; temperature anomalies are not corrected for the direct impact of elevation changes). These results are similar to findings of Driesschaert et al. (2007), who simulated future GIS melting. In addition, the warming over Greenland increases the atmospheric surface temperature in the vicinity of the ice sheet and in regions downwind, such as the region between Greenland and Svalbard, and over the Nordic Seas and Barents Sea. Hence, this warming partly counteracts the FWF-induced surface cooling in the Irminger- and Labrador Sea.

Lowering the elevation of the GIS also interacts with the FWF. Via changes in the large-scale atmospheric circulation, lowering the elevation of the GIS affects deep convection in the Nordic Seas. Since the GIS is a major obstacle for the circumpolar Northern Hemisphere Rossby wave, which substantially contributes to the pattern of high and low pressure systems over the North Atlantic (Hoskins and Karoly, 1981), a lower elevation of the GIS induces a distinct pattern of surface pressure anomalies. Similar to what Ridley et al. (2005) found in simulations for a future climate with a completely melted GIS, both the high pressure system located over the southeast of Greenland and the low pressure system over the Norwegian and Barents Seas are weakened (not shown). The weakening of the low pressure system over the Norwegian and Barents Seas was found to have a negative impact on convection strength and therefore on Norwegian and Barents Sea temperatures (Goosse et al., 2002). In turn, the induced sea surface cooling is compensated for by the warming resulting from higher temperatures upwind. Interestingly, our simulations show that lowering the surface elevation of the GIS not only impacts the Nordic Seas directly, it also enhances the sensitivity of the Nordic Seas overturning strength to the FWF (Fig. 3). Our simulations thus suggest that the overall AMOC strength modulates the decadal variability of the Northern Hemisphere sea-ice volume - as described in Goosse et al. (2002) - involving a coupling between the atmosphere, sea-ice and the ocean. Therefore, as a result of a weakened AMOC, the climate predominately resides in one state of the decadal variability characterized by lower atmospheric temperatures in the Arctic, increased sea-ice volume, and reduced overturning in the Nordic Seas (results not shown here). In regime 3, the combination of the direct impact of lowering the surface elevation of the GIS on the Nordic Seas and the indirect impact of positive 

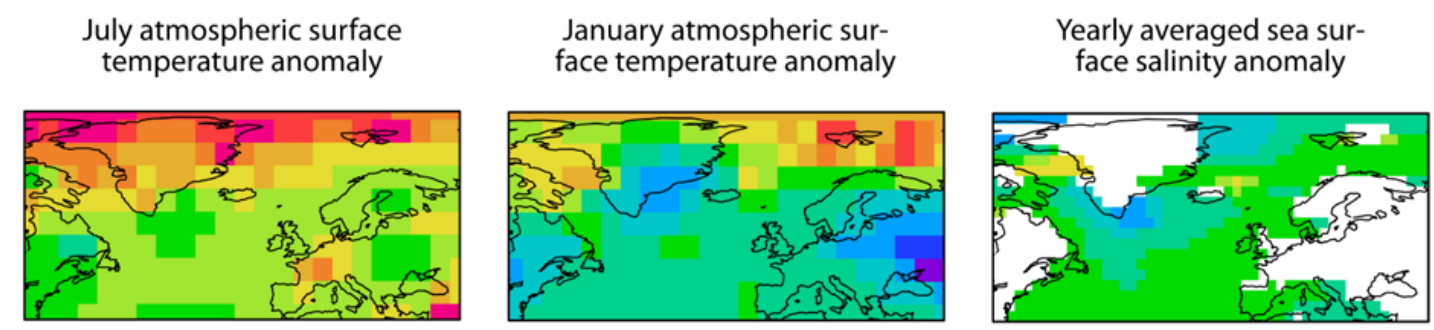

LIG-Ctrl
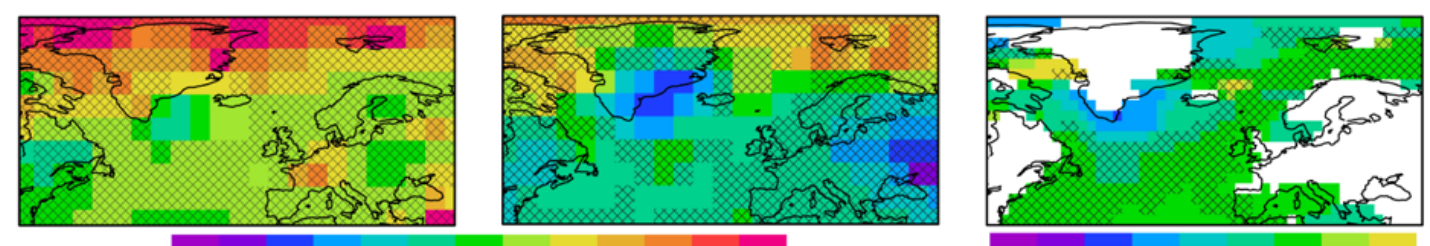

Regime 1

(0.013 Sv)
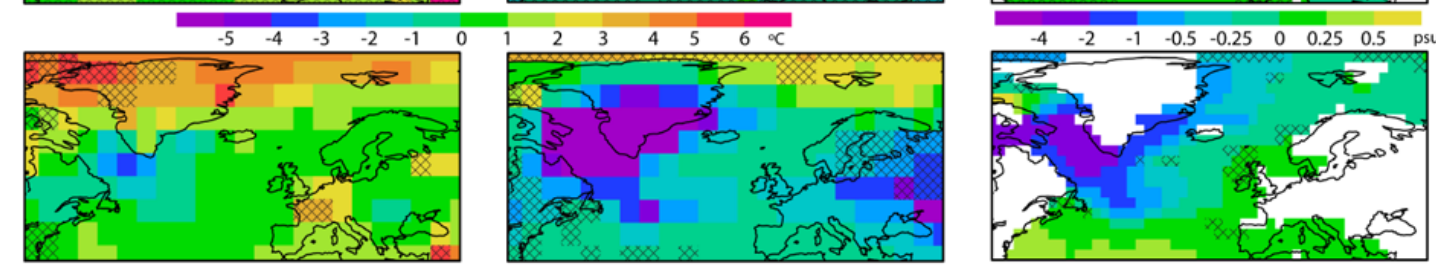

Regime 2

(0.052 Sv)
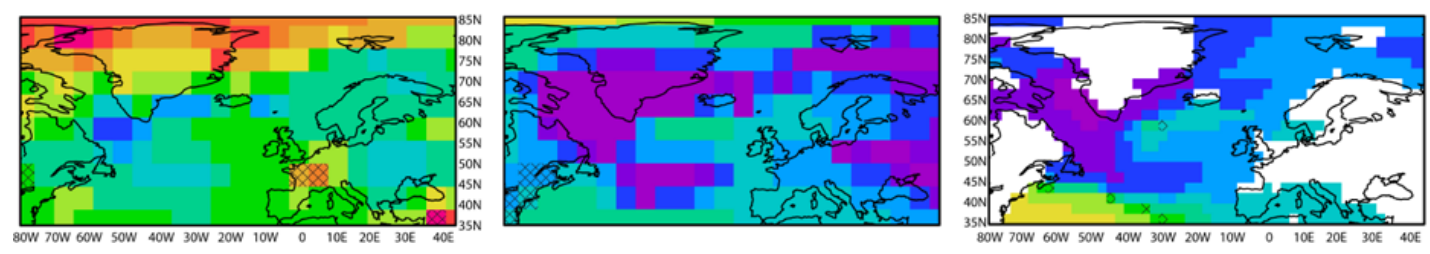

Regime 3

(0.143 Sv)

Fig. 5. Climate anomalies in the North Atlantic region for the LIG-ctrl simulation (top panel) and the 3 climate regimes, compared to PI. Left: July atmospheric surface temperatures $\left({ }^{\circ} \mathrm{C}\right)$; middle: January atmospheric surface temperatures $\left({ }^{\circ} \mathrm{C}\right)$; right: sea surface salinity (psu). Non-hatched areas indicate the regions for which the simulated anomalies are significantly different at the $5 \%$ significance level from the LIG-ctrl anomalies with respect to internal climate variability in the LIG-ctrl simulation (calculated with a t-test).

feedback to the FWF results in a further $14 \%$ decrease of the strength of the AMOC in addition to the FWF-induced changes (Fig. 3).

Incorporating changes in the elevation and extent of the GIS in the simulations provides a first insight into their impact on Greenland temperatures, on climate in the Nordic Seas and on the relationship between decadal variability of the Northern Hemisphere sea-ice volume and FWF. However, the latter relationship in particular requires a more thorough investigation, which lies beyond the scope of this study. Nonetheless, it is interesting to note that over some areas the impact of GIS melting and the changes in surface elevation and ice sheet extent cancel each other out. This is visible in regime 2 north of Svalbard (Fig. 6), where the July temperature increase is no longer significant as soon as GIS elevation and albedo changes are taken into account. The same holds true for Eastern Europe and parts of the Irminger Sea.

Summarizing these results, we obtain a distinct spatial pattern of LIG July surface temperature changes, a fingerprint of the impact of GIS melting on the climate in the North Atlantic region. These highlight the influence of different melt rates of the GIS and the impact of changes in elevation and extent of the ice sheet. Here we focus on July surface temperature anomalies compared to LIG-ctrl in preparation of the model-data comparison in Sect. 3.5. In regime 1, the lower and smaller GIS induces local warming over Greenland, the adjacent ocean waters, and over the waters between northern Greenland and Svalbard. In regime 2, GIS melting results in a $\sim 4^{\circ} \mathrm{C}$ cooling - compared to the LIG-ctrl simulation - over the Labrador Sea (see also Fig. 7) and a cooling of around $\sim 1^{\circ} \mathrm{C}$ over the North Atlantic Ocean between $40^{\circ} \mathrm{N}$ and $70^{\circ} \mathrm{N}$. In addition to these changes, regime 3 is characterized by a cooling of up to $4{ }^{\circ} \mathrm{C}$ in the Nordic Seas and over Scandinavia.

\subsection{Constraints on LIG deep ocean circulation}

In order to constrain the range of simulated LIG climates, we compare the simulated deep ocean circulation in the three regimes with proxy-based reconstructions.

Based on reconstructions of vertical water column stratification in the Labrador Sea, Hillaire-Marcel et al. (2001) concluded that no LSW was formed during the LIG. However, Rasmussen et al. (2003) opposed this view. Using benthic 


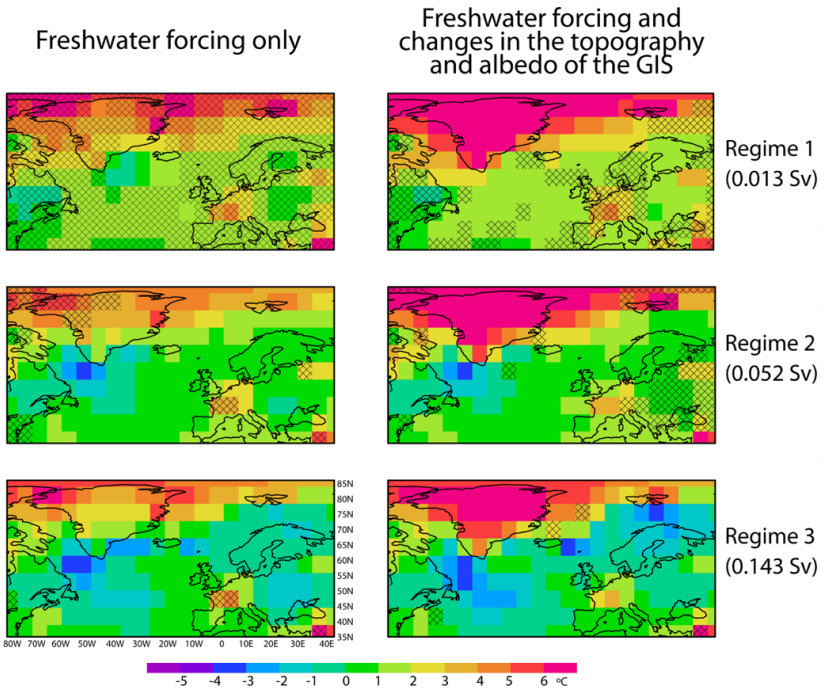

Fig. 6. Comparison of atmospheric July surface temperature anomalies $\left({ }^{\circ} \mathrm{C}\right)$ in the North Atlantic region for the 3 regimes (top to bottom) compared to the PI-ctrl. Figures on the left-hand side depict simulations with only FWF and on the right-hand side with both FWF and changes in the elevation and extent of the GIS. Nonhatched areas indicate the regions for which the simulated anomalies are significantly different at the $5 \%$ significance level from the LIG-ctrl anomalies with respect to internal climate variability in the LIG-ctrl simulation (calculated with a t-test).

$\delta^{13} \mathrm{C}$ reconstructions, they concluded that, during Termination 2 and the early LIG, a weakly ventilated, LSW-like water mass should have been present at intermediate depth in the Labrador Sea region. However, it was (possibly) formed outside the Labrador Sea and flowed in from the east. For the later part of the LIG, Rasmussen et al. (2003) reconstructed Labrador Sea surface and bottom water conditions comparable to modern-day conditions. Other reconstructions of LSW formation during the LIG are available from studies on sediment cores recovered adjacent to the Labrador Sea. They show that LSW formation was either both weaker and occurring at shallower depth or that it was absent altogether (Evans et al., 2007; Hodell et al., 2009). Although the characteristics of the ocean circulation in the Labrador Sea during the LIG remain unresolved, these proxy-based studies suggest that LSW formation was weak or absent during the early LIG, ruling out the oceanographic situation found in regime 1.

LIG deep ocean circulation in the Nordic Seas is also under debate. There are opposing views on the timing of the maximum overturning strength, either coinciding with the insolation optimum (Cortijo et al., 1994, 1999) or occurring during a later part of the interglacial (Rasmussen et al., 2003; Bauch and Erlenkeuser, 2008; Van Nieuwenhove et al., 2008, 2011; Govin et al., 2012). Although our simulations suggest that GIS melting could have affected the overturning circulation in the Nordic Seas - possibly delaying maximum strength until after the insolation optimum - a very large melt
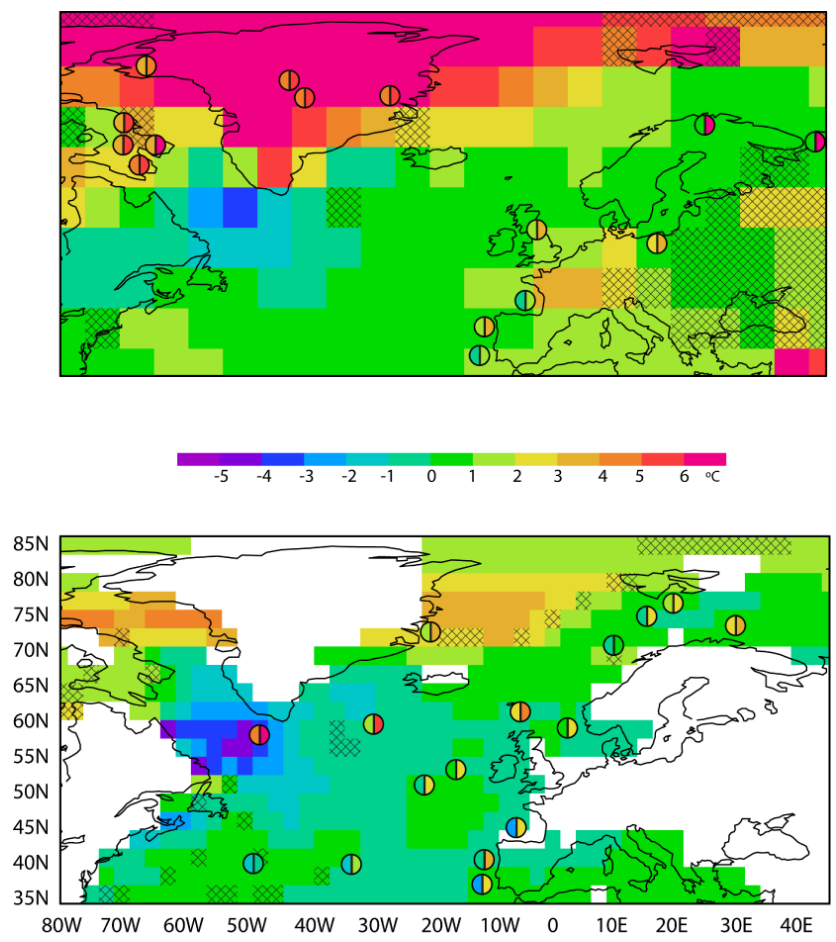

Fig. 7. Model-data comparison for atmospheric July surface temperature anomalies (upper panel) and August sea surface temperature anomalies (lower panel; ${ }^{\circ} \mathrm{C}$ ). Shown are results from regime 2 including the impact of changes in elevation and extent of the GIS compared to the PI-ctrl. Non-hatched areas indicate the regions for which the simulated anomalies are significantly different at the $5 \%$ significance level compared to internal climate variability in the LIG-ctrl simulation (calculated with a t-test). Circles indicate maximum LIG proxy-based temperatures from the CAPE-dataset (CAPE-members, 2006) complemented with data of Hillaire-Marcel et al. (2001) and Sánchez Goñi et al. (2005, 2008, 2012). The left-hand side of the circles depicts the minimum and the right-hand side the maximum estimate of the reconstructed temperatures. Because of the coarse resolution of the model we have decided to incorporate several data points even though they fall at least partly outside of the significantly impacted area.

rate of over $0.130 \mathrm{~Sv}$ would have been needed. Such a flux is at the very high end of the range of reconstructed FWFs. Therefore our model results suggest that it is unlikely that GIS melting strongly reduced deep water formation in the Nordic Seas during the LIG. Assuming that the AMOC in our model has a reasonable sensitivity to a FWF, our results suggest that the most likely climate state for the early part of the LIG is regime 2 .

\subsection{Impact of GIS melting on LIG climate}

In the LOVECLIM model, the most likely state of the LIG climate under the influence of a partial melting of the GIS is characterized by a fingerprint of significant surface temperature anomalies in specific regions. Comparing these anomaly 
patterns with temperature reconstructions helps us understand the impact of a melting GIS on the LIG climate.

To date, the most comprehensive compilation of LIG temperature reconstructions has been compiled by the CAPEmembers (2006). They mapped maximum LIG Arctic summer temperature anomalies based on a range of different terrestrial, oceanic and ice core-related proxies. To circumvent large uncertainties in dating LIG geological records, the data compilation does not represent temperature reconstructions of a specific age, but rather maps the highest LIG summer temperatures for each record. We have extended the modeldata comparison with maximum LIG summer temperature reconstructions from the Iberian coastal waters (Sánchez Goñi et al., 2005, 2008, 2012) and the Labrador Sea (HillaireMarcel et al., 2001) for a better spatial coverage of the North Atlantic region. These reconstructed temperatures are compared to simulated temperature anomalies in regime 2 , including the impact of changes in elevation and extent of the GIS. Even though the imposed changes in surface elevation and extent of the ice sheet are simplistic, we propose that the resulting ice sheet configuration resembles the LIG situation better than the PI configuration would. We use July surface temperatures on land and August sea surface temperatures for marine sites, corresponding to the warmest months. The uncertainty in reconstructed temperatures is taken into account by plotting the maximum and minimum values on the right- and left-hand side of the circles in Fig. 7, respectively.

For most continental sites (Fig. 7, top panel), the simulated July surface temperatures are within the range of the reconstructed temperatures, most notably over Western Europe, the Iberian Peninsula and northern Scandinavia. Exceptions are found over the southern part of Baffin Island and Eastern Europe, where the simulated temperature anomalies are smaller than those reconstructed, while over the GIS the simulated anomalies are larger than those reconstructed (Fig. 7). The model-data comparison for marine sites (Fig. 7, bottom panel) shows a rather similar pattern. For most of the central and eastern North Atlantic Ocean, the simulated temperatures are in agreement with the reconstructions. However, over the Labrador Sea, reconstructions show $\sim 5^{\circ} \mathrm{C}$ higher summer sea surface temperatures, in stark contrast to a simulated cooling of $4{ }^{\circ} \mathrm{C}$ when compared to the PI. Smaller differences between simulated and reconstructed temperatures are found in the Irminger Sea, north of Scotland and in the Barents Sea.

Although the results of the model-data comparison are somewhat ambiguous for some locations, an overall geographical pattern is revealed: good correspondence over the central and eastern part of the North Atlantic, and a mismatch over the Labrador Sea, the Irminger Sea and the southern part of Baffin Island. This pattern matches the simulated fingerprint of July surface temperatures in regime 2. If GIS melting forced the climate into regime 2 during the early LIG, this would imply that reconstructed LIG maximum summer temperatures in the Labrador Sea, the Irminger
Sea and over southern Baffin Island were reached later in the LIG. A delayed thermal maximum relative to the insolation maximum has also been suggested by Renssen et al. (2009) for the early Holocene, during which the climate was forced by melting of the Laurentide Ice Sheet. This interpretation depends heavily on the surface temperature mismatch over the Labrador Sea. However, temperature reconstructions have not revealed cooler conditions in this region during the early LIG (Hillaire-Marcel et al., 2001). According to our simulations, the shutdown of deep convection in the Labrador Sea leads to lower sea surface temperatures in that region. The discrepancy between the simulated and reconstructed climatic setting in the Labrador Sea can have different causes. It is possible that deep convection in the Labrador Sea is too sensitive to GIS melt in this model, even though simulations with the LOVECLIM model have shown a reasonably good performance for the warm climate of the early Holocene (Renssen et al., 2009), the $8.2 \mathrm{ka}$ event (Renssen et al., 2001), and the present-day climate (Goosse et al., 2010). The discrepancy might also originate from difficulties in comparing proxy point data with coarse model output. Alternatively, cooler early LIG sea surface conditions may have been misinterpreted as belonging to the preceding deglaciation. An intercomparison of different climate models or a better age control on the proxy record could go a long way to resolving the issue. Another region where simulated summer surface temperatures are at odds with proxy reconstructions is the Barents Sea. Although this might suggest that this area has also been impacted by GIS melting, the results of the model-data comparison are ambiguous at this point, as the simulations do agree with temperature reconstructions from the Norwegian Sea. Interestingly, our simulations suggest that the influence of GIS melting on the Norwegian and Barents Seas region is not solely the result of the freshwater flux, but of both the freshwater flux and the atmospheric response to the reduced elevation and extent of the GIS. Though a clear explanation for the rather large modeldata mismatch for the site north of Scotland is elusive, the reconstructed temperature here is somewhat of an outlier compared to nearby sites.

\section{Discussion}

\subsection{LIG and future melt rates of the GIS}

The GIS melting rates of between 0.052 and $0.130 \mathrm{~Sv}$, which produce the most likely LIG climate state, are significantly larger than those found in different proxy- and modellingbased studies (up to $0.013 \mathrm{~Sv}$ ). However, as these studies present average values over the whole LIG, melt rates might have been significantly larger during shorter periods of time, possibly a couple of hundreds of years. This is likely since for several periods of up to $400 \mathrm{yr}$, maximum rates of global sea-level change of up to $0.290 \mathrm{~Sv}$ - including an important 
though uncertain contribution of the GIS - have been reconstructed for the LIG (Rohling et al., 2008). The range of LIG GIS melt rates found in this study is also very similar to predictions of future GIS melting. When forcing a version of LOVECLIM1.0 coupled to an active ice-sheet model with increased greenhouse gas concentrations (IPCC SRES A2-scenario), Driesschaert et al. (2007) simulated freshwater fluxes from the GIS evolving from around $0.030 \mathrm{~Sv}$ up to $0.080 \mathrm{~Sv}$ in the course of several centuries. Moreover, based on the extrapolation of GIS mass loss measurements, Rignot et al. (2011) estimated an average freshwater flux of $0.033 \pm 0.013 \mathrm{~Sv}$ until the year 2100 . Potentially, the simulated LIG AMOC sensitivity can be used to assess the strength of the AMOC in the coming centuries. In doing so we find that, in line with Driesschaert et al. (2007), predicted meltwater fluxes will not be sufficient to shut down the AMOC, nor will they substantially cool the climate in Europe. However, predicted melt fluxes are similar to the fluxes for which we simulated a significant impact on deep convection in the Labrador Sea.

It is, however, important to note that the resulting range of GIS melt rates is strongly model-dependent and partly restricted by the setup of the scenario and initial conditions of our simulations. It is therefore crucial to compare these findings with similar experiments performed using other climate models and different model setups.

\subsection{Other mechanisms preventing LSW formation}

GIS melting is a likely culprit in inhibiting deep convection in the Labrador Sea during the early LIG. However, as there are many uncertainties involved in simulating the impact of GIS melting on the LIG climate, it cannot be ruled out that an alternative mechanism prevented deep convection in the Labrador Sea. For instance, increased transport and melt of Arctic sea-ice could have freshened the East and West Greenland Currents, potentially leading to weakening of Labrador Sea deep convection. Furthermore, part of the sea-level high stand during the LIG has been attributed to partial melting of the West Antarctic Ice Sheet (e.g. Overpeck et al., 2006). The effect of this freshwater flux on the climate is still poorly understood, but it could potentially weaken the AMOC (Swingedouw et al., 2009) and therewith provide an alternative mechanism for the reconstructed changes in the LIG climate of the North Atlantic region.

\subsection{Assessing model uncertainties}

Although climate models offer a very useful tool to investigate past climate variability, findings on the simulated sensitivity of the climate to certain perturbations depend heavily on uncertainties in the physics, parameter-set (tuning) and applied forcing scenario. Here, we discuss the performance of our LOVECLIM simulations with respect to the most important uncertainties.
As shown by Stouffer et al. (2006), the LOVECLIM EMIC performs reasonably well in describing the relationship between FWFs and the overturning strength in the North Atlantic. However, Stouffer et al. (2006) also show that the exact location and sensitivity of the deep convection site in the Labrador Sea is highly model-dependent. So, although LOVECLIM simulates deep convection in the correct region under present-day forcings, deep convection changes in the Labrador Sea region should be interpreted with care.

Aside from model-dependent climate sensitivity, a second major source of uncertainties is related to the applied forcing scenario. The scenarios were set up as equilibrium experiments forced with $130 \mathrm{kaBP}$ orbital configuration and greenhouse gas concentrations, and with a combination of changes in the GIS elevation, extent and meltwater flux. The choice of $130 \mathrm{ka}$ BP forcings is somewhat arbitrary, as the timing of the period of enhanced GIS melt during the LIG is uncertain. Although the orbital and greenhouse gas forcings do not differ largely within the interglacial, and timing of their changes is (relatively) well constrained, small differences might cause the climate to cross a threshold and therewith potentially have large implications on the described results. Further, simulations with a reduction in GIS surface elevation and extent suggest a strong response in the regional atmospheric circulation. However, despite that similar effects on the atmospheric circulation were found in other studies (e.g. Lunt et al., 2004; Vizcaíno et al., 2008), corroborating our findings, models containing a more detailed and realistic representation of the atmospheric physics and dynamics are better suited for further in-depth research into this process. Nevertheless, our range of sensitivity experiments systematically dealt with the uncertainty in the GIS meltwater flux.

Finally, three major assumptions made in the setup of the scenarios are a third source of uncertainty. Firstly, simulations start from a climate characterized by deep water formation in both the Nordic and Labrador Seas. It is possible that deep convection did not occur on a sustained basis in these regions during the early LIG (Hillaire-Marcel et al., 2001), because it was inhibited by the meltwater release during the preceding deglaciation up to that time. However, this would not exclude melting of the GIS as an important mechanism that inhibited deep convection after the deglaciation. Secondly, a constant FWF is prescribed in the simulations, while short periods of high meltwater production could have had a profound and lasting influence on the ocean dynamics. Thirdly, the PI configuration of all global ice sheets except the GIS was left unchanged in our sensitivity experiments. From sea level reconstructions it has been proposed that the major ice sheets had already melted away at the beginning of the LIG and that sea level was, at most, a couple of metres below its high stand. However, this does not rule out the possibility that some glacial ice remained, providing meltwater to different parts of the world's oceans - such as the Southern Ocean or the Norwegian and Barents Seas. Since the focus of this study is on the impact of the GIS melting, 
we have adopted the assumption that the configuration and meltwater input of other ice sheets into the ocean was similar to present-day.

\subsection{Outlook}

The LIG climate was not in equilibrium at the moment GIS melting commenced. Rather, the time varying orbital and greenhouse gas forcings led to transient climatic changes. Performing transient simulations including a range of GIS melting scenarios may provide valuable insight into additional feedbacks and the importance of the timing and duration of GIS melting. Future research will be dedicated to this and will complement the results described here. Furthermore, future research will concentrate on performing simulations that include the carbon cycle, to provide a more direct comparison with proxy-based reconstructions of the past overturning circulation.

\section{Conclusions}

We have tested the model's sensitivity to LIG GIS melting and our main findings are listed below.

- We simulated three different climate regimes, characterized by a fingerprint of surface temperature and sea surface salinity changes, as a function of the magnitude of the early LIG GIS melt rate. The main difference between the three regimes is the rate of deep water formation in the Nordic Seas and the Labrador Sea. Deep convection takes place in both the Labrador and the Nordic Seas, solely in the Nordic Seas or in neither of the two regions in regimes 1 to 3 , respectively.

- Based on the simulated AMOC strength and the absence of deep convection in the Labrador Sea, the simulated deep ocean circulation in regime 2 appears to be most consistent with proxy-based reconstructions for the LIG. The GIS melt rate needed to obtain this climate regime in our simulations, a flux between $0.052 \mathrm{~Sv}$ and $0.130 \mathrm{~Sv}$ for several centuries at most, is at the upper bound of estimates in the literature.

- By comparing the simulated July surface temperatures for regime 2 with reconstructed maximum LIG summer temperatures, we show that melting of the GIS possibly delayed the LIG thermal maximum in the western part of the North Atlantic region relative to the insolation maximum, and therefore inhibited the formation of Labrador Sea Water during the early LIG.

- The simulated cooling of Labrador Sea surface waters in regime 2 is not in accordance with LIG temperature reconstructions. Furthermore, in our simulations the GIS melt rates needed to inhibit deep convection in the Labrador Sea are larger than those reconstructed.
These findings stress that, in order to properly estimate the impact of possible future GIS melting, more research is needed to unravel the climate evolution of this potentially crucial part of climate history.

Acknowledgements. The useful comments of the two anonymous reviewers and the editor A. Paul are gratefully acknowledged. This is Past4Future contribution no. 19. The research leading to these results has received funding from the European Unions Seventh Framework programme (FP7/2007-2013) under grant agreement no. 243908, "Past4Future. Climate change - Learning from the past climate".

Furthermore, we acknowledge the fruitful discussion with Sánchez Goñi, M. F. from the Environnements et Paléoenvironnements Océaniques group in Bordeaux.

Edited by: A. Paul

\section{References}

Alley, R. B., Andrews, J. T., Brigham-Grette, J., Clarke, G. K. C., Cuffey, K. M., Fitzpatrick, J. J., Funder, S., Marshall, S. J., Miller, G. H., Mitrovica, J. X., Muhs, D. R., Otto-Bliesner, B. L., Polyak, L., and White, J. W. C.: History of the Greenland Ice Sheet: paleoclimatic insights, Quaternary Sci. Rev., 29, 17281756, 2010.

Bacon, S., Gould, W. J., and Jia, Y.: Open-ocean convection in the Irminger Sea, Geophys. Res. Lett., 30, 1246-1250, doi:10.1029/2002GL016271, 2003.

Barber, D., Dyke, A., Hillaire-Marcel, C., Jennings, A., Andrews, J. T., Kerwin, M., Bilodeau, G., McNeely, R., Southon, J., Morehead, M., and Gagnon, J.: Forcing of the cold event of 8.200 years ago by catastrophic drainage of Laurentide lakes, Nature, 400, 344-348, 1999.

Bauch, H. A. and Erlenkeuser, H.: A critical climatic evaluation of last interglacial (MIS 5e) records from the Norwegian Sea, Polar Res., 27, 135-151, 2008.

Berger, A. L.: Long-term variations of caloric insolation resulting from the earth's orbital elements, Quaternary Res., 9, 139-167, 1978.

Broecker, W. S., Bond, G., Klas, M., Bonani, G., and Wolfli, W.: A Salt Oscillator in the Glacial Atlantic? 1. The Concept, Paleoceanography, 5, 469-477, 1990.

Brovkin, V., Bendtsen, J., Claussen, M., Ganopolski, A., Kubatzki, C., Petoukhov, V., and Andreev, A.: Carbon cycle, vegetation, and climate dynamics in the Holocene: Experiments with the CLIMBER-2 model, Global Biogeochem. Cy., 16, 1139-1159, doi:10.1029/2001GB001662, 2002.

CAPE-members: Last Interglacial Arctic warmth confirms polar amplification of climate change, Quaternary Sci. Rev., 25, 13831400, 2006.

Carlson, A. E., Stoner, J. S., Donnelly, J. P., and Hillaire-Marcel, C.: Response of the southern Greenland Ice Sheet during the last two deglaciations, Geology, 36, 359-362, 2008.

Chen, J. H., Curran, H. A., White, B., and Wasserburg, G. J.: Precise chronology of the last interglacial period: $234 \mathrm{U}-230 \mathrm{Th}$ data from fossil coral reefs in the Bahamas, Geol. Soc. Am. Bull., 103, 8297, 1991. 
Colville, E. J., Carlson, A. E., Beard, B. L., Hatfield, R. G., Stoner, J. S., Reyes, A. V., and Ullman, D. J.: Sr-Nd-Pb Isotope Evidence for Ice-Sheet Presence on Southern Greenland During the Last Interglacial, Science, 333, 620-623, 2011.

Cortijo, E., Duplessy, J. C., Labeyrie, L., Leclaire, H., Duprat, J., and van Wearing, T. C. E.: Eemian cooling in the Norwegian Sea and North Atlantic ocean preceding continental ice-sheet growth, Nature, 372, 446-449, 1994.

Cortijo, E., Lehman, S., Keigwin, L., Chapman, M., Paillard, D., and Labeyrie, L.: Changes in Meridional Temperature and Salinity Gradients in the North Atlantic Ocean $\left(30^{\circ}-72^{\circ} \mathrm{N}\right)$ during the Last Interglacial Period, Paleoceanography, 14, 23-33, 1999.

Cuffey, K. M. and Marshall, S. J.: Substantial contribution to sealevel rise during the last interglacial from the Greenland ice sheet, Nature, 404, 591-594, 2000.

Driesschaert, E., Fichefet, T., Goosse, H., Huybrechts, P., Janssens, I., Mouchet, A., Munhoven, G., Brovkin, V., and Weber, S. L.: Modeling the influence of Greenland ice sheet melting on the Atlantic meridional overturning circulation during the next millennia, Geophys. Res. Lett., 34, L10707, doi:10.1029/2007GL029516, 2007.

Evans, H. K., Hall, I. R., Bianchi, G. G., and Oppo, D. W.: Intermediate water links to Deep Western Boundary Current variability in the subtropical NW Atlantic during marine isotope stages 5 and 4, Paleoceanography, 22, PA3209, doi:10.1029/2006PA001409, 2007.

Goosse, H. and Fichefet, T.: Importance of ice-ocean interactions for the global ocean circulation: A model study, J. Geophys. Res., 104, 23337-23355, 1999.

Goosse, H., Selten, F. M., Haarsma, R. J., and Opsteegh, J. D.: A mechanism of decadal variability of the sea-ice volume in the Northern Hemisphere, Clim. Dynam., 19, 61-83, 2002.

Goosse, H., Brovkin, V., Fichefet, T., Haarsma, R., Huybrechts, P., Jongma, J., Mouchet, A., Selten, F., Barriat, P.-Y., Campin, J.M., Deleersnijder, E., Driesschaert, E., Goelzer, H., Janssens, I., Loutre, M.-F., Morales Maqueda, M. A., Opsteegh, T., Mathieu, P.-P., Munhoven, G., Pettersson, E. J., Renssen, H., Roche, D. M., Schaeffer, M., Tartinville, B., Timmermann, A., and Weber, S. L.: Description of the Earth system model of intermediate complexity LOVECLIM version 1.2, Geosci. Model Dev., 3, 603-633, doi:10.5194/gmd-3-603-2010, 2010.

Govin, A., Braconnot, P., Capron, E., Cortijo, E., Duplessy, J.-C., Jansen, E., Labeyrie, L., Landais, A., Marti, O., Michel, E., Mosquet, E., Risebrobakken, B., Swingedouw, D., and Waelbroeck, C.: Persistent influence of ice sheet melting on high northern latitude climate during the early Last Interglacial, Clim. Past, 8, 483-507, doi:10.5194/cp-8-483-2012, 2012.

Hastings, D., Dunbar, P., Elphingstone, G., Bootz, M., Murakami, H., Maruyama, H., Masaharu, H., Holland, P., Payne, J., Bryant, N., Logan, T., Muller, J., Schreier, G., and MacDonald, J.: The Global Land One-kilometer Base Elevation (GLOBE) Digital Elevation Model, Version 1.0., National Oceanic and Atmospheric Administration, National Geophysical Data Center, 325 Broadway, Boulder, Colorado 80305-3328, USA, 1999.

Hillaire-Marcel, C., de Vernal, A., Bilodeau, G., and Weaver, A. J.: Absence of deep-water formation in the Labrador Sea during the last interglacial period, Nature, 410, 1073-1077, 2001.

Hodell, D. A., Minth, E. K., Curtis, J. H., McCave, I. N., Hall, I. R., Channell, J. E. T., and Xuan, C.: Surface and deep-water hydrog- raphy on Gardar Drift (Iceland Basin) during the last interglacial period, Earth Planet. Sc. Lett., 288, 10-19, 2009.

Hofmann, M. and Rahmstorf, S.: On the stability of the Atlantic meridional overturning circulation, P. Natl. Acad. Sci., 106 20584-20589, 2009.

Hoskins, B. J. and Karoly, D. J.: The Steady Linear Response of a Spherical Atmosphere to Thermal and Orographic Forcing, J. Atmos. Sci., 38, 1179-1196, 1981.

Israelson, C. and Wohlfarth, B.: Timing of the Last-Interglacial High Sea Level on the Seychelles Islands, Indian Ocean, Quaternary Res., 51, 306-316, 1999.

Joussaume, S. and Braconnot, P.: Sensitivity of paleoclimate simulation results to season definitions, J. Geophys. Res., 102, 19431956, 1997.

Koerner, R. M.: Ice Core Evidence for Extensive Melting of the Greenland Ice Sheet in the Last Interglacial, Science, 244, 964 968, 1989.

Kopp, R. E., Simons, F. J., Mitrovica, J. X., Maloof, A. C., and Oppenheimer, M.: Probabilistic assessment of sea level during the last interglacial stage, Nature, 462, 863-867, 2009.

Krabill, W., Hanna, E., Huybrechts, P., Abdalati, W., Cappelen, J., Csatho, B., Frederick, E., Manizade, S., Martin, C., Sonntag, J., Swift, R., Thomas, R., and Yungel, J.: Greenland Ice Sheet: Increased coastal thinning, Geophys. Res. Lett., 31, L24402, doi:10.1029/2004GL021533, 2004.

Kuhlbrodt, T., Griesel, A., Montoya, M., Levermann, A., Hofmann, M., and Rahmstorf, S.: On the driving processes of the Atlantic meridional overturning circulation, Rev. Geophys., 45, RG2001, doi:10.1029/2004RG000166, 2007.

Letréguilly, A., Huybrechts, P., and Reeh, N.: Steady-state characteristics of the Greenland ice sheet under different climates, Journal of Glaciology, 37, 149-157, 1991.

Lhomme, N., Clarke, G. K. C., and Marshall, S. J.: Tracer transport in the Greenland Ice Sheet: constraints on ice cores and glacial history, Quaternary Sci. Rev., 24, 173-194, 2005.

Lunt, D. J., de Noblet-Ducoudré, N., and Charbit, S.: Effects of a melted greenland ice sheet on climate, vegetation, and the cryosphere, Clim. Dynam., 23, 679-694, 2004.

Masson-Delmotte, V., Braconnot, P., Hoffmann, G., Jouzel, J., Kageyama, M., Landais, A., Lejeune, Q., Risi, C., Sime, L., Sjolte, J., Swingedouw, D., and Vinther, B.: Sensitivity of interglacial Greenland temperature and $\delta^{18} \mathrm{O}$ : ice core data, orbital and increased $\mathrm{CO}_{2}$ climate simulations, Clim. Past, 7, 10411059, doi:10.5194/cp-7-1041-2011, 2011.

McCulloch, M. T. and Esat, T.: The coral record of last interglacial sea levels and sea surface temperatures, Chem. Geol., 169, 107129, 2000.

Muhs, D. R., Simmons, K. R., and Steinke, B.: Timing and warmth of the Last Interglacial period: new U-series evidence from Hawaii and Bermuda and a new fossil compilation for North America, Quaternary Sci. Rev., 21, 1355-1383, 2002.

Nakicenovic, N., Alcamo, J., Davis, G., de Vries, B., Fenhann, J., Gaffin, S., Gregory, K., Grubler, A., Jung, T. Y., Kram, T., La Rovere, E. L., Michaelis, L., Mori, S., Morita, T., Pepper, W., Pitcher, H. M., Price, L., Riahi, K., Roehrl, A., Rogner, H.-H., Sankovski, A., Schlesinger, M., Shukla, P., Smith, S. J., Swart, R., van Rooijen, S., Victor, N., and Dadi, Z.: Special Report on Emissions Scenarios: A Special Report of Working Group III of the Intergovernmental Panel on Climate Change, Cambridge 
University Press, Cambridge, UK, 599 pp., 2000.

Opsteegh, J. D., Haarsma, R. J., Selten, F. M., and Kattenberg, A.: ECBILT: a dynamic alternative to mixed boundary conditions in ocean models, Tellus A, 50, 348-367, 1998.

Otto-Bliesner, B. L., Brady, E. C., Clauzet, G., Tomas, R., Levis, S., and Kothavala, Z.: Last Glacial Maximum and Holocene Climate in CCSM3, J. Climate, 19, 2526-2544, 2006.

Overpeck, J. T., Otto-Bliesner, B. L., Miller, G. H., Muhs, D. R., Alley, R. B., and Kiehl, J. T.: Paleoclimatic Evidence for Future IceSheet Instability and Rapid Sea-Level Rise, Science, 311, 17471750, 2006.

Rahmstorf, S.: Bifurcation of the Atlantic thermohaline circulation in response to changes in the hydrological cycle, Nature, 378, 145-149, 1995.

Rahmstorf, S., Crucifix, M., Ganopolski, A., Goosse, H., Kamenkovich, I., Knutti, R., Lohmann, G., Marsh, R., Mysak, L. A., Wang, Z., and Weaver, A. J.: Thermohaline circulation hysteresis: A model intercomparison, Geophys. Res. Lett., 32, L23605, doi:10.1029/2005GL023655, 2005.

Rasmussen, T. L., Oppo, D. W., Thomsen, E., and Lehman, S. J.: Deep sea records from the southeast Labrador Sea: Ocean circulation changes and ice-rafting events during the last 160,000 years, Paleoceanography, 18, 1018, doi:10.1029/2001PA000736, 2003.

Renssen, H., Goosse, H., Fichefet, T., Campin, J., and M: The 8.2 kyr BP event simulated by a Global Atmosphere-Sea-IceOcean Model, Geophys. Res. Lett., 28, 1567-1570, 2001.

Renssen, H., Goosse, H., and Fichefet, T.: Modelling the effect of freshwater pulses on the early Holocene climate: The influence of high-frequency climate variability, Paleoceanography, 17, 116, doi:10.1029/2001PA000649, 2002.

Renssen, H., Seppa, H., Heiri, O., Roche, D. M., Goosse, H., and Fichefet, T.: The spatial and temporal complexity of the Holocene thermal maximum, Nat. Geosci., 2, 411-414, 2009.

Ridley, J. K., Huybrechts, P., Gregory, J. M., and Lowe, J. A.: Elimination of the Greenland Ice Sheet in a High $\mathrm{CO}_{2}$ Climate, J. Climate, 18, 3409-3427, 2005.

Rignot, E., Velicogna, I., van den Broeke, M. R., Monaghan, A., and Lenaerts, J.: Acceleration of the contribution of the Greenland and Antarctic ice sheets to sea level rise, Geophys. Res. Lett., 38, L05503, doi:10.1029/2011GL046583, 2011.

Roche, D. M., Wiersma, A. P., and Renssen, H.: A systematic study of the impact of freshwater pulses with respect to different geographic locations, Clim. Dynam., 34, 997-1013, 2010.

Rohling, E., Grant, K., Hemleben, C., Siddal, M., Hoogakker, B., Bolshaw, M., and Kucera, M.: High rates of sea-level rise during the last interglacial period, Nat. Geosci., 1, 38-42, 2008.

Sánchez Goñi, M. F., Loutre, M. F., Crucifix, M., Peyron, O., Santos, L., Duprat, J., Malaizé, B., Turon, J. L., and Peypouquet, J. P.: Increasing vegetation and climate gradient in Western Europe over the Last Glacial Inception (122-110 ka): data-model comparison, Earth Planet. Sc. Lett., 231, 111-130, 2005.

Sánchez Goñi, M. F., Landais, A., Fletcher, W. J., Naughton, F., Desprat, S., and Duprat, J.: Contrasting impacts of DansgaardOeschger events over a western European latitudinal transect modulated by orbital parameters, Quaternary Sci. Rev., 27, 1136-1151, 2008.

Sánchez Goñi, M. F., Bakker, P., Desprat, S., Carlson, A. E., Meerbeeck, C. J., Peyron, O., Naughton, F., Fletcher, W. J., Eynaud, F.,
Rossignol, L., and Renssen, H.: European climate optimum and enhanced Greenland melt during the Last Interglacial, Geology, in press, 2012.

Schmitz, W. J.: On the interbasin-scale thermohaline circulation, Rev. Geophys., 33, 151-173, 1995.

Schulz, M., Prange, M., and Klocker, A.: Low-frequency oscillations of the Atlantic Ocean meridional overturning circulation in a coupled climate model, Clim. Past, 3, 97-107, doi:10.5194/cp3-97-2007, 2007.

Smith, R. S. and Gregory, J. M.: A study of the sensitivity of ocean overturning circulation and climate to freshwater input in different regions of the North Atlantic, Geophys. Res. Lett., 36, L15701, doi:10.1029/2009GL038607, 2009.

Solomon, S., Qin, D., Manning, M., Chen, Z., Marquis, M., Averyt, K., Tgnor, M., and Miller, H.: IPCC, 2007: Climate Change 2007: The Physical Science Basis. Contribution of Working Group I to the Fourth Assessment Report of the Intergovernmental Panel on Climate Change, Cambridge University Press, Cambridge, United Kingdom and New York, NY, USA, 996 pp., 2007.

Stirling, C. H., Esat, T. M., McCulloch, M. T., and Lambeck, K.: High-precision U-series dating of corals from Western Australia and implications for the timing and duration of the Last Interglacial, Earth Planet. Sc. Lett., 135, 115-130, 1995.

Stirling, C. H., Esat, T. M., Lambeck, K., and McCulloch, M. T.: Timing and duration of the Last Interglacial: evidence for a restricted interval of widespread coral reef growth, Earth Planet. Sc. Lett., 160, 745-762, 1998.

Stommel, H.: Thermohaline Convection with Two Stable Regimes of Flow, Tellus, 13, 224-230, 1961.

Stouffer, R. J., Yin, J., Gregory, J. M., Dixon, K. W., Spelman, M. J., Hurlin, W., Weaver, A. J., Eby, M., Flato, G. M., Hasumi, H., Hu, A., Jungclaus, J. H., Kamenkovich, I. V., Levermann, A., Montoya, M., Murakami, S., Nawrath, S., Oka, A., Peltier, W. R., Robitaille, D. Y., Sokolov, A., Vettoretti, G., and Weber, S. L.: Investigating the Causes of the Response of the Thermohaline Circulation to Past and Future Climate Changes, J. Climate, 19, 1365-1387, 2006.

Swingedouw, D. and Braconnot, P.: Effect of the Greenland IceSheet melting on the response and stability of the AMOC in the next century, Geoph. Monog. Series, 173, 383-392, doi:10.1029/173GM24, 2007.

Swingedouw, D., Mignot, J., Braconnot, P., Mosquet, E., Kageyama, M., and Alkama, R.: Impact of Freshwater Release in the North Atlantic under Different Climate Conditions in an OAGCM, J. Climate, 22, 6377-6403, 2009.

Tarasov, L. and Peltier, W. R.: Greenland glacial history, borehole constraints, and Eemian extent, J. Geophys. Res., 108, 2143, doi:10.1029/2001JB001731, 2003.

Van Nieuwenhove, N., Bauch, H. A., and Matthiessen, J.: Last interglacial surface water conditions in the eastern Nordic Seas inferred from dinocyst and foraminiferal assemblages, Mar. Micropaleontol., 66, 247-263, 2008.

Van Nieuwenhove, N., Bauch, H. A., Eynaud, F., Kandiano, E., Cortijo, E., and Turon, J.-L.: Evidence for delayed poleward expansion of North Atlantic surface waters during the last interglacial (MIS 5e), Quaternary Sci. Rev., 30, 934-946, 2011.

Vezina, J., Jones, B., and Ford, D.: Sea-level highstands over the last 500,000 years; evidence from the Ironshore Formation on Grand 
Cayman, British West Indies, J. Sediment. Res., 69, 317-327, 1999.

Vizcaíno, M., Mikolajewicz, U., Gröger, M., Maier-Reimer, E., Schurgers, G., and Winguth, A.: Long-term ice sheet climate interactions under anthropogenic greenhouse forcing simulated with a complex Earth System Model, Clim. Dynam., 31, 665690, 2008

Weaver, A. J., Bitz, C. M., Fanning, A. F., and Holland, M. M.: THERMOHALINE CIRCULATION: High-Latitude Phenomena and the Difference Between the Pacific and Atlantic, Annu. Rev. Earth Pl. Sc., 27, 231-285, 1999.
Wiersma, A. P. and Renssen, H.: Model-data comparison for the $8.2 \mathrm{ka}$ BP event: confirmation of a forcing mechanism by catastrophic drainage of Laurentide Lakes, Quaternary Sci. Rev., 25, 63-88, 2006.

Wood, R. A., Keen, A. B., Mitchell, J. F. B., and Gregory, J. M.: Changing spatial structure of the thermohaline circulation in response to atmospheric $\mathrm{CO}_{2}$ forcing in a climate model, Nature, $399,572-575,1999$. 